\title{
Knowledge of Sports Motivation: The Consumptive Lifestyle of a Running Community
}

\author{
$1^{\text {st }}$ Yopy Perdana Kusuma \\ Communication Science Study \\ Program \\ Universitas Muhammadiyah \\ Tangerang \\ Jl. Perintis Kemerdekan 1/33 Cikokol- \\ Kota Tangerang, Indonesia \\ perdana_aspro@yahoo.com
}

\author{
$2^{\text {nd }}$ Abdul Basit \\ Communication Science Study \\ Program \\ Universitas Muhammadiyah \\ Tangerang \\ Jl. Perintis Kemerdekan 1/33 Cikokol- \\ Kota Tangerang, Indonesia
}

\author{
$3^{\text {rd }}$ Muhamad Amaludin \\ Communication Science Study \\ Program \\ Universitas Muhammadiyah \\ Tangerang \\ Jl. Perintis Kemerdekan 1/33 Cikokol- \\ Kota Tangerang, Indonesia
}

\begin{abstract}
The life of modern society in general cannot be separated from the lifestyle in their daily lives. The lifestyle in question for example can be reflected in fashion, habits or even in sports activities. That is, exercise is not just an activity that intersects with health alone, but also has become part of the lifestyle. Running, for example, which tends to be known as an easy and affordable sport, is now no longer seen as a sporting activity for maintaining health, but also a part of lifestyle. Based on the background of the problem, this study aims to determine and explain the motivations of the runners who make running as part of their lifestyle. Using a qualitative approach, the results of this study indicate that running sport gives a different impression to every running community in Indonesia and running sport is no longer a sporting activity to maintain health merely as shown by the motivation of runners to join the community.
\end{abstract}

Keywords-Knowledge, Sports motivation, consumptive lifestyle, running community

\section{INTRODUCTION}

Running has become more popular than in the previous twenty years. At that time, the sport of running can only be enjoyed by a limited circle, especially athletes. In fact, the results of the Susenas show the participation of residents aged 10 years and over in doing sports has decreased from time to time. The increase in sports participation only occurred from 2000 by $22.6 \%$ towards 2003 to 25.4\%. During 2003, 2006 and 2009, population participation in sports continued to decline, from $25.4 \%$ in 2003 , down to $23.2 \%$ in 2006 , and lastly down to $21.8 \%$ in 2009 [1].

Along with the times, especially since 2009, the existence of a running sports community also experienced a very dynamic and rapid development. This can be observed for example from the emergence of various community runners, for example the Indorunners Community, Nike Runners, Tangerang Crazy Runners, and others. In addition, various running sports events also began to experience very rapid developments both at the regional and national levels between 2016 and 2018 (Gerintya, 2018; Yudha, 2018). At this point, runners can be said to start to realize their lifestyle or make running as part of a lifestyle [1]-[5]. The role of communication both by word of mouth and through social media that allows interpersonal communication between members of the community well [6]-[8]. Interpersonal communication in which motivation plays an important role in attaching individuals who are members of the community [9].

In Indonesia, running is a sport that is very popular with the public. Besides being easy to do, this sport can also make you feel happy (fun). Running sports are also more desirable than swimming or cycling. In Southeast Asia running sports occupy a percentage of $54 \%$ of the sports categories of interest, while in Indonesia there is a percentage of $60 \%$ [10]. Based on these data, it certainly does not rule out the possibility that this sports-loving community is experiencing rapid development and popping up in various regions [11], [12]. Table 1 below can show how running has been transformed or transformed from mere sport into a lifestyle. Table 1 also looks at the roles and support of both government and private agencies.

TABLE 1. RUNNING EVENTS IN INDONESIA APRIL AND MAY 2019

\begin{tabular}{|l|c|c|}
\hline \multicolumn{1}{|c|}{ Event } & Time & Location \\
\hline Royal Safari Garden & 21 April 2019 & Bogor \\
\hline Banteng Raides Trail Run & 21 April 2019 & Semarang \\
\hline JCO Run 2019 & 28 April 2019 & Tangerang Selatan \\
\hline Cleo Smart Run & 28 April 2019 & Bali \\
\hline Setneg KemayoRun & 28 April 2019 & DKI Jakarta \\
\hline RunNation 2019 & 28 April 2019 & DKI Jakarta \\
\hline Mandiri Yogya Marathon & 28 April 2019 & Yogyakarta \\
\hline EnviroRun & 28 April 2019 & Semarang \\
\hline New Bhakti 10K & 28 April 2019 & Surabaya \\
\hline IT Telkom Purwekorto City Run & 28 April 2019 & Purwokerto \\
\hline Spot Finding Run 2019 & 28 April 2019 & Makassar \\
\hline
\end{tabular}




\begin{tabular}{|l|c|c|}
\hline Ramadhan Run 2019 & 5 May 2019 & Virtual Run \\
\hline Mother's Day Virtual Run 2019 & 12 May 2019 & Virtual Run \\
\hline Bintaro Jaya 10K & 18 May 2019 & Tangerang Selatan \\
\hline Burners Ramadhan Night Race & 18 May 2019 & Cibubur \\
\hline Lungs On The Run 50K & 30 May 2019 & Virtual Run \\
\hline
\end{tabular}

\section{source: www.ayolari.in}

In this study, the communities that were the subject of the research were the community runners in Jakarta and Tangerang. At this point and as the community develops, the health benefits of running are combined with the lifestyles of the individuals who are incorporated, such as accessories (headbands, glasses, clothing) and others [13]-[15]. Furthermore, community members are also willing to spend an insignificant amount of money to meet the needs of a number of accessories / equipment. In fact, these needs are not included in primary needs and are classified as consumptive needs. The phenomenon, more or less shows that running, maybe also other sports, has experienced a shift in meaning, from merely supporting health activities to being a part of "lifestyle" [16], [17].

\section{LiterATURE REVIEW}

\section{A. Interpersonal Communication}

According to Mulyana (in Suranto, 2011) interpersonal communication (interpersonal communication) is communication between people face to face, which allows participants to capture other people's reactions directly both verbally and nonverbally. According to DeVito (2011), interpersonal communication is the delivery of messages by one person and the receipt of messages by another person / small group of people, with various impacts and with opportunities to provide immediate feedback. Meanwhile, according to Gitosudarmo and Mulyono (in Suranto, 2011) interpersonal communication is face-toface communication, person-to-person interaction, twoway, verbal and nonverbal, and sharing information and feelings between individuals in a small group [18].

Communication itself has many principles and styles, and without realizing it, we often do interpersonal communication styles (face to face) with other people who have the same interests. The interactions carried out are reciprocal or bidirectional both verbally and nonverbally.

\section{B. Group Communication}

According to Mulyana (2013) a group is "a group of people who have a common goal, interact with each other to achieve a common goal (interdependence), get to know each other and view them as part of the group even though each member may have a different role "[19]. According to Bungin (2006), group communication is "the intensity of the relationship between them which is the main requirement of the people in the group". The group also has its own goals and rules and is a contribution to the flow of information among members so that it can create a group attribute as a unique identity and is closely attached to the group [20]. Meanwhile, Burgoon (in Wiryanto, 2005) defines group communication as face-to-face interaction between three or more people, with known goals, such as sharing information, protecting themselves, solving problems. In daily life, group communication also sometimes goes unnoticed; nonlinear communication is considered to be very important when deciding on a policy. Usually, in an association /community that is communicating, they already have a clear and purposeful goal.

\section{Motivation}

Herzberg (in Uno, 2007) states that health factors do not encourage employee interest. However, if these factors are deemed unsatisfactory in many respects, for example because salaries are not high enough or working conditions are unpleasant, they become a strong source of potential dissatisfaction . According to Oemar Hamalik (2005) motivation is a change of energy in a person that is characterized by the emergence of a feeling of reaction to achieve goals [21]. Meanwhile, according to McDonald (in Sardirman, 2014) motivation is a change in energy in a person which is characterized by the emergence of feeling and preceded by a response to the existence of goals.

\section{Community}

According to Iriantara (2004), a community is a group of individuals who inhabit a location and are usually associated with the same interests. According to Wenger, McDermott and Synder (2002), a community is a group of people who share a problem, concern / interest in a topic and deepen their knowledge and expertise by interacting continuously. According to Kartajaya (2008) a community is a social group of several organisms whose various environments generally have the same relationships and habitats. Meanwhile, according to Seokanto (1985) community can be interpreted as part of a society based on the same feeling, common sense, and mutual need and residing in an area of residence.

\section{E. Life Style}

The term lifestyle or life style was originally introduced by Max Weber (2009) which states that a person's social status is mainly determined by "lifestyle" which is more determined by how to consume than the way people produce. According to Kotler \& Keller (2009) lifestyle (life style) is a person's lifestyle in the world that is reflected in the activities, interests and opinions. While according to Mowen and Minor (2001) lifestyle is a pattern of life behavior of individuals, patterns in shopping and allocating time ". Lifestyle is more synonymous with consumptive behavior of individuals in order to get a good self-image and be seen in the upper class / others. Lifestyle forming factors 
according to Bourdieu (in Piliang, 2006) can be seen from a series of longer processes involving capital, objective conditions, habitus, disposition, lifestyle practices, sign systems and tastes.

\section{3. RESEARCH METHOD}

This research is descriptive-qualitative in nature. Using the phenomenological method, the subjects in this study were community runners in Tangerang City and Jakarta. Data collection techniques used were observation, interviews and documentation studies, while data analysis techniques used interactive analysis of Miles and Huberman.

\section{DATA RESUlTS AND ANALYSIS}

So, this community was founded not to make its members as sports athletes. In its activities, this sporting activity cannot be avoided from the urban lifestyle of urban communities which tend to lead to comfort. In this community, for example, this can be seen from the various attributes used by its members as a means to support comfort and safety in sports (running), from shoes to comfortable clothes when worn. In addition, the informants also stated that running has become part of an increasingly dynamic lifestyle (urban society), one of which can be seen from the many competitions or running events and the growing fertility of running lovers communities in various regions in Indonesia. In fact, furthermore, this sports community is also widely established both within the commercial and noncommercial institutions.

\section{A. Running as a Positive Lifestyle}

As part of a positive lifestyle, running sports activities give a different impression to each informant. Informant 2 states that running is a lifestyle that has many positive benefits for the culprit, especially for the body and mind. Even informant 2 also encouraged the running community to grow and develop in other places so that running activities can be done together and fun. Deeper, informant 2 sees that the runners community can be a means for charity activities so that it can have a positive impact on the wider community. Another benefit felt by informants 4 is that it can be an event or means of gathering with other communities. Furthermore, so that this sport can be increasingly favored by the community, informant 4 stated that the involvement of public figures is needed that is able to influence the public regarding the various benefits behind running. That is, the presence of public figures can be a driver to arouse public interest [22].

For Informant 1, running is already considered a part of lifestyle. That is, this sport is no longer just identical for athletes, but can also be enjoyed by all people. This can be proven by the development of Tangerang Runner which already has around 70 members from the original only 5 members when it was founded in 2017 and there are more running communities in Jakarta. As part of lifestyle, this sport cannot be separated from various attributes that are more or less a symbol of social status for its users.

"In the past, running was synonymous with athletes. Now it has changed. Running is also not just running, because there are many accessories that really need to be considered, starting from shoes, belts, clothes, and others. "(Informant 1)

While informant 3 , who is a coaching clinic, said that first of all this sport was driven by an awareness of people who were increasingly "aware" of the importance of health by doing regular exercise. Second, there are actors who campaign for the importance of sport for physical and spiritual health. When this sport is getting more familiar and can even be said to be booming, support also comes from various events that are held to enliven running sports activities. At this point, Event Organizer (EO) also plays an important role in making running sports a lifestyle trend.

\section{B. Motivation Maintaining a Running Lifestyle and Self-Existence}

In achieving a goal behind it there is motivation that encourages each individual to achieve it. In the view of informant 2, who has also participated in various marathon events such as $10 \mathrm{~K}, 21 \mathrm{~K}$ to $42 \mathrm{~K}$, the motivation that drives him is sourced from both internal and external factors. From external factors, what motivates is the friendship environment that has first been active in running sports, then from the internal comes the drive to be able to realize a healthy body and spirit. Meanwhile, in terms of maintaining the existence and solidity of the community, including how to develop the community, informant 1 used social media tools to show the existence of the community runners. In fact, based on the statement of informant 1, it was social media that made the runners community able to survive and thrive.

"Through social media, we always invite, post interesting information, also to share our activities that are daily, weekly, monthly and at the same time become promotional media. Tangerang Runners also has a group chat specifically for active members. "(Informant 1)

Furthermore, informant 1, who is also the Chairperson of Tangerang Runners, indeed makes the community a fun gathering place. That is, the exercises held are not merely considered as a burden that must be achieved so as to eliminate the motivation of other members who may have been burdened with their activities. At this point, interpersonal communication within the community (group) is very important in maintaining the motivation of each member so that what is embedded in the mind is running as a fun (sport) activity. Motivation for example is the need for a lifestyle or "life style". This means that various attributes (accessories) attached to running sport also have an important role, especially in attaching a social status to its users. According to the informant, there were even members who were trained to buy shoes for 12 million. However, beyond that, community members (runners) have also become increasingly aware of the various 
health benefits that are obtained other than just showing self-consistency.

\section{Style in Running Also Need to be Considered}

Related to the lifestyle trends that are inherent in this running sport activity, informant 1 emphasized that the activity did not have to be "supported" by excessive facilities (accessories / attributes). The statement of informant 1 is also further supported by the statement of informant 2 which states that the community has never emphasized the style (accessories) that lead to certain social status symbols. In the context of this research and the community of runners, the word "style" tends to be more appropriate if interpreted as accessories that provide comfort and safety, not as symbols or attributes that represent the "social status" of individual users. Other informants also "agreed" that the Tangerang Runners had never prioritized style; what comes first is the pleasure and other benefits that can be obtained from gathering and running. For informants 4, enough with street pants, watches and light running shoes can be fashionable. Or in other languages:

"The most important thing is how to run, look for sweat. The shoes are not a matter of price, but a matter of comfort and don't make feet scratch easily.

"(Informant 4)

From the above explanation, it can be said that the motivations of community members differ from each other, although there is one thing in common, namely in order to obtain various health benefits.

\section{CONCLUSION}

One of the aims of establishing a community of runners is to develop a healthy lifestyle for the people of Tangerang and Jakarta. As part of a positive lifestyle (life stye), running sports activities give a different impression to each member (runners), ranging from various health benefits that can be obtained up to as a means or container for communication between members. In maintaining its activities each member also has a different motivation from one another. However, it can be concluded that internal motivation plays a greater role in each member, which in turn contributes to the sustainability of the community.

\section{REFERENCES}

[1] Y. Prasetyo, "Kesadaran Masyarakat Berolahraga untuk Peningkatan Kesehatan dan Pembangunan Nasional," MEDIKORA, vol. 11, no. 2, 2013.

[2] G. Gumilar, I. M. Kusmayadi, and I. Zulfan, "Komunitas Olah Raga Untuk Kaum Urban Bandung: Membangun Jaringan Komunikasi Melalui Media Sosial," Jurnal Riset Komunikasi, vol. 1, no. 1, pp. 158-169, 2018.

[3] N. E. Salam and R. Ramadha, "Konsep Diri Komunitas Liburun Tentang Gaya Hidup Sehat di Kota Pekanbaru," Jurnal Online Mahasiswa Fakultas Ilmu Sosial dan Ilmu Politik Universitas Riau, vol. 3, no. 1, 2016

[4] A. D. Henning, "Health culture and running: Non-elite runners' understandings of doping and supplementation," Journal of amateur sport, vol. 1, no. 2, p. 51, 2015 .

[5] E. Malchrowicz-Mośko and J. Poczta, "Running as a form of therapy socio-psychological functions of mass running events for men and women," International journal of environmental research and public health, vol. 15, no. 10, p. 2262, 2018
[6] T. D. Baruah, "Effectiveness of Social Media as a tool of communication and its potential for technology enabled connections: A micro-level study," International Journal of Scientific and Research Publications, vol. 2, no. 5, pp. 1-10, 2012.

[7] P. Matthews, "Social media, community development and social capital," Community Development Journal, vol. 51, no. 3, pp. 419-435, 2016

[8] Shahreza, M, Abdul Basit, and Fitri S. Isbandi., "Teknologi Komunikasi sebagai Pelekat Hubungan Menuju Pernikahan Lintas Budaya," Prosiding Konferensi Nasional Komunikasi ISKI, vol. 2, no. 1, pp. 142-161, 2018.

[9] S. M. Paterson, "Online learning: motivational factors for success," International Journal of Recent Contributions from Engineering, Science \& IT (iJES), 2014.

[10] S. Gerintya, "Lari, Indonesia, Lari! - Tirto.ID," 01/042018. [Online]. Available: https://tirto.id/lari-indonesia-lari-cCHS. [Accessed: 14-Oct-2019].

[11] C. Marquis and J. Battilana, "Acting globally but thinking locally? The enduring influence of local communities on organizations," Research in organizational behavior, vol. 29, pp. 283-302, 2009.

[12] M. Kilpatrick, E. Hebert, and J. Bartholomew, "College students' motivation for physical activity: differentiating men's and women's motives for sport participation and exercise," Journal of American college health, vol. 54, no. 2, pp. 87-94, 2005.

[13] L. Middlemiss, "The power of community: how communitybased organizations stimulate sustainable lifestyles among participants," Society \& Natural Resources, vol. 24, no. 11, pp 1157-1173, 2011

[14] L. Middlemiss, "The effects of community-based action for sustainability on participants' lifestyles," Local Environment, vol. 16, no. 3, pp. 265-280, 2011.

[15] R. Gordon, L. Gurrieri, and M. Chapman, "Broadening an understanding of problem gambling: The lifestyle consumption community of sports betting," Journal of Business Research, vol. 68, no. 10, pp. 2164-2172, 2015.

[16] B. MacCosham, P. Patry, C. Beswick, and F. Gravelle, "Leisure lifestyle and dropout: Exploring the experience of amateur athletes in competitive sport," International Journal of Sport Management, Recreation and Tourism, vol. 20, no. 2, pp. 20-39, 2015.

[17] P. Gilchrist and B. Wheaton, "Lifestyle sport, public policy and youth engagement: Examining the emergence of parkour,' International journal of sport policy and politics, vol. 3, no. 1, pp. 109-131, 2011.

[18] J. Devito, “Komunikasi Antarmanusia.(terjemahan)," Jakarta Penerbit Profesional, 1997.

[19] D. Mulyana, Ilmu komunikasi: suatu pengantar. Bandung: Remaja Rosdakarya, 2013.

[20] B. Bungin, "Komunikasi pariwisata (tourism communication) Pemasaran dan brand destinasi," Jakarta: Prenadamedia Group, 2015.

[21] O. Hamalik, Pengembangan Sumber Daya Manusia Manajemen Pelatihan Ketenagakerjaan Pendekatan Terpadu. 2005.

[22] A. Basit and R. A. Hudaya, "Pengaruh Endorser Valentino Rossi Yamaha N-Max Terhadap Minat Produk Komunitas N-Max Tangerang," Jurnal Ilmiah LISKI (Lingkar Studi Komunikasi), vol. 4, no. 2, pp. 91-103, 2018. 